Maurice A. Deane School of Law at Hofstra University Scholarly Commons at Hofstra Law

Hofstra Law Faculty Scholarship

2013

\title{
Osler, Langdell, and the Atelier: Three Tales of Creation in Professional Education
}

Richard K. Neumann Jr.

Maurice A. Deane School of Law at Hofstra University

Follow this and additional works at: https://scholarlycommons.law.hofstra.edu/faculty_scholarship

\section{Recommended Citation}

Richard K. Neumann Jr., Osler, Langdell, and the Atelier: Three Tales of Creation in Professional Education, 10 Legal Comm. \& Rhetoric: JAWLD 151 (2013)

Available at: https://scholarlycommons.law.hofstra.edu/faculty_scholarship/280

This Article is brought to you for free and open access by Scholarly Commons at Hofstra Law. It has been accepted for inclusion in Hofstra Law Faculty Scholarship by an authorized administrator of Scholarly Commons at Hofstra Law. For more information, please contact lawcls@hofstra.edu. 


\title{
Osler, Langdell, and the Atelier: Three Tales of Creation in Professional Education
}

\author{
Richard K. Neumann, Jr.*
}

Osler: In 1885, a young physician teaching at the University of Pennsylvania medical school received a telegram from a friend, the superintendent of an Ontario asylum. The telegram read, "Please see Walt and tell me how he is." By reply wire, the physician asked, "Who is Walt, and where does he live?" Then, and well into the twentieth century, physicians routinely made house calls.

After another telegram answered his questions, the physician crossed the Delaware River to Camden by ferry, knocked on the door of the address he had been given, and found inside an elderly man, surrounded by papers and surprised to be visited by a doctor. Later describing the pointlessness of his errand, the physician wrote that he had encountered

a fine figure of a man who had aged beautifully, or more properly speaking, majestically, with a large frame and well-shaped, well-poised head, covered with a profusion of snow-white hair which mingled in the cheeks with a heavy, long beard and moustache... [ [He] seemed lost in a hirsute canopy. The grey eyes had a kindly sympathetic look; the skin was fresh and clear, wrinkled only in the forehead. The nose was large \& straight; the mouth was hidden by the moustache. Though high-pitched, his voice was clear and musical, and the words uttered slowly in short sentences.... I felt a bit embarrassed, as professional advice seemed superfluous.... I left with the pleasant impression of having seen a splendid old man, and a room the grand disorder of which filled me with envy. ${ }^{1}$

At that moment, the younger of these two did not fully realize the older's eminence. And the older could not have foreseen the worldwide

\footnotetext{
* Professor of Law, Maurice A. Deane School of Law at Hofstra University. I'm grateful to Joan Magat and Jeff Jackson for
} insightful editing and to Tolu Akinsanya for thorough research assistance. 
reputation the younger man would later acquire. Although the physician enjoyed the "splendid old man" and his magnificent clutter, returning that evening to Philadelphia and locating a copy of Leaves of Grass, he found that he did not like the older man's poetry at all. ${ }^{2}$ Walt Whitman was in his fading years and had been revising the book's last edition. The physician, William Osler, had arrived in Philadelphia the year before from Canada and would soon be hired away by trustees connected with the estate of a Baltimore entrepreneur.

They hired Osler because of his growing reputation as a diagnostician. Before modern technology, diagnostic skill-discovering what is happening inside the sealed container of a human body-rested entirely on the power of observation. Osler had to rely on eye and ear-as he had with Whitman-as well as touch, to find exterior signs of health or the lack of it within. In photographs, he is seen staring at a patient's stomach or chest with slow deliberation and in deep concentration, from different angles in relation to the patient and the source of light, looking for abnormalities so slight in appearance that it takes time and the right shade of light to see them. Then, he sits and thinks, still gazing at the patient.

The Baltimore entrepreneur was Johns Hopkins, who had wanted to build a hospital, an orphanage for African-American children, a nursing school, a medical school, and a university. His estate endowed trusts for all these purposes. ${ }^{3}$ The trustees built the hospital before the medical school and university, and they hired Osler as the hospital's physician-in-chief. ${ }^{4}$ There, together with like-minded colleagues, he invented the structure and sequence of study in the typical four-year medical degree program together with its core feature: bedside teaching in a hospital.

Langdell: The Harvard Law School faculty in 1870 had only three members. Formal faculty meetings were superfluous. But one did occur that September, attended and chaired by the university president. Among other things on the agenda was election of a law dean. With so small a faculty, the position had not existed before, but a university president could eventually become uncomfortable with a few professors teaching as they pleased and no accountability for what they were up to. No one knew what a deanship might entail, but it seemed to include some recordkeeping and other tedious tasks.

2 Id. at 1142-43. Whitman's opinions of Osler appear in Philip W. Leon, Walt Whitman and Sir William Osler: A Poet and His Physician (1995).

3 Bliss, supra note 1, at 168; Death of Johns Hopkins: His Last illness Life and Character His Career as a Merchant and Banker His Benevolent Enterprises Monuments of Learning and Charity, Ec., Baltimore Sun (Dec. 25, 1873).

4 Bliss, supra note 1 , at $167,172$. 
Two of the professors present were senior in every respect and not immune from the tendency in faculties for old bulls to hope that young teachers will do the unpleasant work. The third had been hired the preceding January and was thus as junior as it was possible to be. The university president awaited a nomination. Finally, one of the old bulls suggested the newcomer, Christopher Columbus Langdell, and he was elected with two ayes and one abstention (his own). ${ }^{5}$

Almost immediately, Langdell invented the casebook and the law school version of the Socratic dialog. It's not widely understood that, with help from James Barr Ames, he also took a leading role in developing most of the other core features of traditional American legal education: the traditionally required curriculum; the three-year degree; the essay exam; the library's role as the center of the law school; a classroom faculty with relatively little experience or interest in practice; the student-edited law review; and the Langdellian bargain - a general understanding between universities and their law schools about the kind of revenue a law school would generate, how it would be divided between the law school and its university, and how the law school's share would be allocated internally.

The atelier: American architectural education was created not by individuals like Osler and Langdell, but instead developed from a kind of place-the French atelier, from which the modern architectural design studio is descended. An architecture school is built around its design studio, and architectural education's values and practices are studio values and practices. The history of architectural education is essentially the history of the atelier and its evolution into the design studio.

The preponderant image of architectural education is a student learning to create at a designing board while other students do the same nearby, each occasionally visited by a teacher who comments, questions, and sometimes conducts a silent dialog, through sketches, with the student. The preponderant image of medical education is young people in white coats hesitantly taking patient histories in hospital wards. In legal education, the predominant image is the large classroom of first-year and other core courses, the teacher professing to and occasionally interrogating an audience of a hundred or more students. Everything else in legal education is considered to be a variation of, a deviation from, or a supplement to that model.

History and storytelling reveal where we are through how we got there. Medicine, law, and architecture entered universities as subjects of 
serious study in the late nineteenth century almost simultaneously. But they entered in different ways and on different terms. Their three parallel stories show how legal education diverged from the norms being established in the other two. Over several generations, that divergence led to the current crisis in law schools, which-unlike medical and architecture schools-are insulated from their own practicing profession and are preoccupied with matters that the profession considers only marginally relevant. Among the consequences are unnecessary financial burdens imposed on students and lawyers without their knowledge or oversight. To explain how that happened and why, this article compares the stories of medical education as Osler and his colleagues created it (Part I) with architectural education and its core feature, the design studio (Part II) and with legal education and its defining Langdellian characteristics (Part III). Part 4 concludes.

\section{Osler}

$[\mathrm{H}$ [ave no teaching without a patient for a text ... [T $\mathrm{T}]$ he best teaching is that taught by the patient himself.

- William Osler

Until the end of the nineteenth century, medical education consisted almost entirely of lecture. Medical students did not practice medicine under supervision. At most, they observed their teachers practicing. ${ }^{6}$ That's the type of education illustrated in Thomas Eakins' paintings The Gross Clinic and The Agnew Clinic-the surgeon-professor operates on a patient and explains what he is doing while dozens of students watch and listen. Everything changed with the creation of the Johns Hopkins School of Medicine in Baltimore.

Johns Hopkins died in 1873, leaving his fortune to trusts with instructions to build the finest hospital possible and a university with a medical school as well as other philanthropies. ${ }^{7}$ Hopkins' instructions were unique for the era. The hospital was to treat everyone, regardless of race (Maryland had been a slave state only a few years before) and regardless of income (patients with money would pay, subsidizing those who could not). The trustees were largely Quaker businessmen. They were prudent with capital and reluctant to part with it until absolutely confident of the use to which it would be put. They were so careful with the trust's

6 Kenneth M. Ludmerer, Learning to Heal: The Development of American Medical Education 156-57 (1985) (hereinafter Ludmerer, Learning).

7 Bliss, supra note 1, at 168 . 
money that the hospital didn't open until fifteen years after Hopkins' death. He had a vague sense that the hospital and the medical school he was endowing should have some connection with each other. ${ }^{8}$ But he was neither a teacher nor a doctor and had no clear idea of how this would work. In the elite medical schools of the time, it was seen as naive whimsy.

It was fortunate that the trustees built the hospital before the medical school. Shortly before the hospital opened in 1888 , they hired William Osler and appointed him physician-in-chief. ${ }^{9}$ When the school opened five years later, the hospital had become a first-rate treatment facility carefully designed to teach. Osler and his colleagues turned that situation into a new model of medical education: the hospital as an integral part of the medical school, and the medical school as an integral part of the hospital.

Today, the first two years of medical education teach a basic science curriculum in large classrooms while introducing some basic skills outside those classrooms. These are called the preclinical or pre-clerkship years. ("Clinical" refers to the practice of medicine, and a "clinician" is any practicing physician or surgeon.) The third year is often called the year on the wards because it's spent in required clinical rotations, also called clerkships, mostly in a teaching hospital. In the fourth year, students complete their rotations and take some electives. Bedside teaching is what academic medicine calls much of what happens during the clinical years. It constitutes more than a third of the study required for the four-year M.D. degree, which is typically followed by several years of practice under supervision in post-graduate residencies. Decades later, a doctor might remember from a clinical rotation or the beginning of a residency the "patient [who] made me a physician." 10 This is the model of medical education that Osler and his colleagues created at Johns Hopkins.

Osler taught not in a lecture hall, but instead on the wards with the goal of developing in students what he called "clinical wisdom."11 He wrote that in "the natural method of teaching the student begins with the patient, continues with the patient, and ends his studies with the patient, using books and lectures as tools, as means to an end."12 By all accounts, Osler was both a brilliant diagnostician and a brilliant teacher. Among other things, he taught observation - the skill of estimating medical needs by studying a patient's appearance and listening carefully to what the

8 ld. at $168-69$.

$9 \mathrm{Id}$. at 167,172 .

10 Philip Reilly, To Do No Harm: A Journey Through Medical School 180 (1987).

11 Bliss, supra note 1 , at 238.

12 Quoted at W.R. Bett, Osler: The Man and the Legend 74 (1951). 
patient says, as he did with Whitman-a skill often underdeveloped in medicine today because of technologies like MRIs. ${ }^{13}$ He essentially said that if you listen to the patient, he is telling you the diagnosis."14

Not only was Osler the leading figure in the teaching and research of medicine, but he was also a leading figure in the practice of medicine. He became one of the most celebrated physicians in America and Europe and was considered the "most famous, most beloved, and most influential physician" of his time. ${ }^{15}$ Although this seems an extravagant judgment, all published accounts agree with it. Patients were willing to cross an ocean to get his diagnosis. Despite all this Osler wrote that "I desire no other epitaph than the statement that I taught medical students in the wards." 16

Although Osler created the model for modern medical education, it remained to Abraham Flexner to see that every medical school would either convert to that model or cease to exist. Flexner was not a physician, and he never attended a medical school, much less taught in one. He was a strong-willed educational theorist. ${ }^{17}$ The Carnegie Foundation for the Advancement of Teaching commissioned him to investigate the quality of medical education. His book-length report to the Foundation in 1910 is one of the most influential documents in the history of American higher education.

Flexner held every medical school to the standards set at Hopkins, and he described exactly how most of them had failed that standardnaming the schools and detailing their inadequacies. ${ }^{18} \mathrm{He}$ wrote that in the best medical schools " $t$ ] he student no longer merely watches, listens, memorizes; he does. His own activities in the laboratory and in the clinic are the main factors in his instruction and discipline. An education in medicine nowadays [in 1910] involves both learning and learning how; the student cannot effectively know, unless he knows how."19

13 Jerome Groopman, How Doctors Think 170-71 (2007). At least one medical school has hired an artist to teach students to draw the human form so they can learn how to observe it. Katherine Mangan, Learning to See, in Order to Heal, Chron. Higher Educ. A48 (March 2, 2007).

14 Groopman, supra note 13, at 170-71 (quoting Myron Falchuk).

15 Id. at ix, 227.

16 William Osler, Aeguanimitas 388-90 (3d ed. 1932), quoted in Gert H. Brieger, Clinical Teaching and Clinical Science in American Medicine, 1900-1950, 21 Clio Medica 47, 49 (1987-88).

17 See Thomas Neville Bonner, Iconoclast: Abraham Flexner and a Life in Learning (2002); Michael Nevins, Abraham Flexner: A Flawed American Icon (2010); Steven Charles Wheatley, The Politics of Philanthropy: Abraham Flexner and Medical Education (1989).

18 Abraham Flexner, Medical Education in the United States and Canada: A Report to the Carnegie Foundation for the Advancement of Teaching 185-326 (1910) (hereinafter, Flexner Report). See Bliss, supra note 1, at 238; Molly Cooke, David M. Irby \& Bridget C. O'Brien, Educating Physicians: A Call for Reform in Medical School and Residency 12 (2010) (hereinafter Cooke, et al., Educating Physicians); Ludmerer, Learning, supra note 6, at 155; Kenneth M. Ludmerer, Understanding the Flexner Report, 85 Acad. Med. 193 (2010).

19 Flexner Report, supra note 18, at 53. 
The public inferred from Flexner's report that any medical school without comprehensive instruction in a teaching hospital was a fraud. In the year it was published, the medical schools at Columbia, Harvard, and Washington University each acquired a teaching hospital on the Hopkins model. ${ }^{20}$ Later, the worst schools identified by Flexner either closed or were absorbed into stronger institutions that could afford teaching hospitals. Eventually every surviving medical school was connected to a teaching hospital, and it became impossible to operate a credible medical school without one. ${ }^{21}$

Osler's example was that of a first-rate teacher, researcher, and physician. For generations afterward, medical-school faculty members took it as a benchmark that each of them should excel simultaneously in all three realms. "After 1960, however, as medical research became increasingly molecular in orientation, patients were bypassed in most cutting-edge investigations, and immersion in the laboratory became necessary." 22 Resources have shifted to the basic sciences (Ph.D.s researching in laboratories and teaching in large classrooms) and to clinical faculty (M.D.s in faculty practice plans, many of whom no longer do bedside teaching). ${ }^{23}$ Beginning in the 1960 s and increasingly after the 1970s, medical schools obtained more and more of their revenue from faculty practice plans, which increased the number of faculty on the clinical side but did not increase the teaching resources there. ${ }^{24}$

The current economics of medicine have sorely stressed the Oslerian model. A teaching hospital is more expensive to run than an ordinary one, but insurers reimburse only what an ordinary hospital would charge for the same procedure. Because professional time is now rationed according to insurance reimbursement rates, physicians and surgeons everywhere have become so time-stressed that the learning environment in teaching

20 Ludmerer, Learning, supra note 6, at 220.

$21 \mathrm{Id}$. at 229.

22 Molly Cooke, David M. Irby, William Sullivan \& Kenneth M. Ludmerer, American Medical Education 100 Years after the Flexner Report, 355 New Eng. J. Med. 1339 (2006) (hereinafter, Cooke, et al, 100 Years).

23 Ludmerer, Learning, supra note 6, at 261.

24 On average, $53 \%$ of a medical school's revenue derived from faculty practice plans and hospital-related revenue, $28.5 \%$ from grants and contracts for research and similar purposes, $3.5 \%$ from tuition, and the rest from other sources. Assoc. of American Medical Colleges, Revenue of U.S. Medical Schools by Source, at http://www.aamc.org/download/142878/data/ fy 2009 tables/fy $2009 \mathrm{msft}$.pdf. Even before faculty practice plans, clinicians had become the overwhelming majority of medical-school faculties, from $58 \%$ in 1951 to over $80 \%$ today. William G. Rothstein, American Medical Schools and the Practice of Medicine: A History 257 (1987); Assoc. of American Medical Colleges, AAMC Data Book: Statistical Information Related to Medical Schools and Teaching Hospitals 34 (2005). In law schools, however, the ratio is nearly reversed. Clinical and legal writing teachers together are less than $30 \%$ of law school faculties. Association of American Law Schools, Statistical Report on Law Faculty 29-33 (2007-2008). 
hospitals has eroded and opportunities for bedside teaching have become a scarce and precious commodity. ${ }^{25}$

In 2010, a century after its 1910 Flexner Report, the Carnegie Foundation for the Advancement of Teaching published a second examination of medical schools. ${ }^{26}$ Among other things, it found that medical education generally has become "not learner-centered" and that bedside education in particular is assigned to "faculty who have less and less time to teach and who have ceded much of their teaching responsibilities to residents." 27 The intensity, continuity, and reflectiveness of law school clinical and legal writing teaching can strike medical people as being of especially high quality and remind older physicians and surgeons of what they experienced as students during what many consider the golden age of medical education, between Flexner and the 1960s or 1970s.

But medical schools are still more focused on the patient than law schools are on the client. Patients are everywhere in a medical school's most important building, its teaching hospital. A law school casebook teacher, however, would be baffled if asked where the clients are.

Terminology here is revealing. The medical pedagogical literature uses the phrase academic medicine far more often than medical education. In fact, the medical equivalent of the Journal of Legal Education is a journal called Academic Medicine. The JLE is published by the Association of American Law Schools. Academic Medicine is published by the AALS's medical equivalent, the Association of American Medical Colleges.

The term legal education suggests education about the law and things related to the law, which might include, at the margins, the professional capabilities required to practice law. Academic medicine is medicine practiced in the academy inseparably from the teaching and research that goes on there. A physician or a surgeon in academic medicine is a physician or surgeon on a medical school faculty. Except in a law school's clinic, law faculty don't think of themselves as lawyers who teach. They are referred to, and refer to themselves, primarily as law professors, implying that they hold forth on the law-and that discussion of practice and clients is optional.

25 Kenneth M. Ludmerer, Time to Heal: American Medical Education from the Turn of the Century to the Era of Managed Care 18-19 (1999); Rothstein, supra note 24, at 299-301; Cooke, et al, 100 Years, supra note 22, at 1339; David M. Irby, Teaching and Learning in Ambulatory Care Settings: A Thematic View of the Literature, 70 Acad. Med. 898 (1995); Katherine S, Mangan, Physician Teach Thyself, Chron. Higher Educ., Nov. 23, 2003, at A18; Erich Studer-Ellis, Jennifer Gold \& Robert F. Jones, Trends in US Medical School Faculty Salaries, 1988-1989 to 1998-1999, 284 JAMA 1130, 1135 (2000); Robert T. Watson, Rediscovering the Medical School, 78 Acad. Med. 659 (2003). 
Another striking difference "between legal and medical education today is that medical education is based upon evidence about what does, and what does not, constitute effective teaching" while legal education is not. ${ }^{28}$ Academic Medicine is published twelve times a year and is filled almost entirely with empirical research on curriculum and teaching. Its methodological standards are tough. The Journal of Legal Education is distributed to every full-time law teacher in the country but with only four issues a year. Most of the content is nonempirical. Empirical research on legal education is largely published in journals with more limited circulation and is rarely discussed in faculty meetings.

\section{The Atelier}

the emotional power of the design studio experience - Jeffrey Karl Ochsner

Although architecture is a profession, in the company of law and medicine, it's also a fine art, in the company of painting and sculpture. An architect has a client who wishes a building constructed not only for practical purposes but also designed to touch the spirit of those who use it and those who see it from the outside. Typically, the client starts out aware of the practical goals and begins to consider the artistic ones only later, if at all.

The fine art is in how the building is experienced. ${ }^{29}$ To sit at a table in the main reading room of the Library of Congress-under sixteen stories of empty space capped by an enormous and majestic dome--is to feel that the books brought silently by a librarian are treasures. This is what the architect intended. A Manhattan pedestrian turning the corner out of 26 th Street onto Fifth Avenue is confronted with the Flatiron Building, floating above its neighbors as an artistic statement. Even in a home, a good architect can find a way, through the location of a window, to bring into a kitchen soft morning light that transforms a moment of sipping coffee.

A building is also judged by professional criteria. It must be sturdy enough to stand for decades or, ideally, centuries, while providing shelter from the elements. It must satisfy its users' practical needs in details not obvious to the layperson. A corridor a few inches too narrow can create

28 Jennifer S. Bard, "Practicing Medicine and Studying Law": How Medical Schools Used to Have the Same Problems We Do and What We Can Learn from Their Efforts to Solve Them, 10 Seattle J. Soc. Justice 135, 152 (2011). See Jennifer S. Bard, What We in Law Can Learn from Our Colleagues in Medicine About Teaching Students How to Practice Their Chosen Profession, 36 J.L. Med. \& Ethics 841 (2008).

29 See Architects' People (Russell Ellis \& Dana Cuff, eds. 1989). 
foot traffic jams that annoy and inconvenience generations who pass through it. A building must be cost-efficient, in initial construction as well as later maintenance costs and energy usage. And it must satisfy building codes and other forms of regulation. (Karl Llewellyn considered law "cognate to architecture" because its purpose points "so directly and inescapably to use." ${ }^{30} \mathrm{He}$ also considered legal argument to be "closely related to the performing arts-music, drama, dance." ${ }^{31}$ )

Both the profession and the art are learned in the design studio, where students plan buildings, are critiqued in their work, and learn how to think architecturally. ${ }^{32}$ The design studio has dominated American architectural education since the nineteenth century $y^{33}$ and is descended from Parisian ateliers, where students shared space with a master artist or architect, where students critiqued each others' work, and where the master might deliver judgments, either helpful or destructive. ${ }^{34}$ This isn't unique to architecture. An atelier is any artist's workshop. In all the visual arts, atelier learning occurs in the environment of such a place and under the direction (and sometimes tyranny) of the artist. In the nineteenth century, the Parisian atelier was the gold standard of architectural education, and an American who wanted to design buildings typically went to Paris and found an atelier in which to learn.

One of the first Americans to study architecture this way was Richard Morris Hunt, ${ }^{35}$ who, on his return to the United States, designed the Studio Building at 51 West Tenth Street in Manhattan. The Studio Building began the artistic tradition of living and working in Greenwich Village. It had "everything an artist could hope for-heat, good light, camaraderie, a gallery, soirees and wealthy patrons." ${ }^{36}$ Albert Bierstadt, Frederic Church, and Winslow Homer had studios there at one time or another. Hunt took some space for himself and accepted a few young people to work as apprentices and students. This was the first American atelier. $^{37}$

The second was opened in 1866 by Henry Hobson Richardson, who later designed the Copley Square Trinity Church in Boston. He also

30 Karl N. Llewellyn, On the Good, The True, The Beautiful in Law, 9 U. Chi. L. Rev. 224, 230 (1941-1942).

31 Quoted at N.E.H. Hull, Roscoe Pound and Karl Llewellyn: Searching for an American Jurisprudence 276 (1997).

32 Dana Cuff, Architecture: The Story of Practice 63, 121 (1991). See Jeffrey Karl Ochsner, Behind the Mask: A Psychoanalytic Perspective on Interaction in the Design Studio, 53 J. Architectural Educ. 194, 194 (2000).

33 Ernest L. Boyer \& Lee D. Mitgang, Building Community: A New Future for Architecture Education and Practice 15 (1996).

34 See id. at 16; Cuff, supra note 32 , at 28.

35 Cuff, supra note 32 , at 26.

36 Evoking the World of Winslow Homer, N.Y. Times, Aug. 17, 1997. The Studio Building stood for nearly a century until it was demolished in 1956. Id.

37 Cuff, supra note 32, at 26-28. 
designed Austin Hall for Harvard's law school. It was completed in 1884, under Langdell's deanship, and is still in use. After Richardson died in 1886, his architectural practice evolved into a partnership firm, which designed Langdell Hall, part of which was completed and occupied in 1907, the remainder in 1929. The firm also designed the Art Institute of Chicago and the campus of the Harvard Medical School. Under the name Shepley Bulfinch, it still exists and is one of the oldest architectural practices in the United States.

Hunt's and Richard's ateliers became "centers of architectural education. .. . Their emphasis on art, intellect, and theory stood in sharp contrast to the ad hoc training in skills and construction acquired by less aristocratic practitioners of the time." ${ }^{38}$ It took substantial family money then to study without earning an income, for years in an atelier.

When American universities opened architecture schools, they hired atelier-trained faculty, who renamed the atelier the design studio, adapted its practices to a university setting, and created side courses to supplement the studio and prepare students for it. A studio teacher assigns a problem by designating a site and specifying the type of building the student must design for it. ${ }^{39}$ Architectural education assumes that what follows is the most important thing that can happen in an architecture school: one-toone conversations between teacher and student while the student designs. ${ }^{40}$ This kind of teaching and learning led to Donald Schön's general study of professional education, ${ }^{41}$ which has influenced pedagogical literature in other fields, including law. ${ }^{42}$ Most of the examples in Schön's Educating the Reflective Practitioner are drawn from design studio interactions between teachers and students documented in the 1981 Architecture Education Study, ${ }^{43}$ in which Schön participated. He came to

38 Id. at 28.

39 Cuff, supra note 32, at 26-28. Until his death in 1959, Frank Lloyd Wright's atelier was located during the summer at Taliesin in Wisconsin and during the rest of the year at Taliesin West in Arizona. Today it's the Frank Lloyd Wright School of Architecture. Then and now, one of the problems posed to a Wright student is to design, and actually construct, a shelter in the desert in which the student will live, protected, one hopes, from sun and scorpions.

40 Boyer \& Mitgang, supra note 33, at 15-16.

41 Donald A. Schön, Educating the Reflective Practitioner: Toward a New Design for Teaching and Learning in the Professions $(1987,1990)$ (hereinafter, Schön, Educating). Boyer \& Mitgang, supra note 33, at 75; Donald A. Schön, The Design Studio: An Exploration of Its Traditions and Potentials (1985); Donald A. Schön, The Architectural Design Studio as an Example for Reflection in Action," $38 \mathrm{~J}$. Architectural Educ. 2 (1984).

42 Schön's work made such a deep impression among legal educators that he was asked to speak at the annual meeting of the Association of American Law Schools. His talk was published at Donald A. Schön, Educating the Reflective Legal Practitioner, 2 Clin. L. Rev. 231 (1995). For an overview of Schön's influence, see Richard K. Neumann Ir, Donald Schön, the Reflective Practitioner, and the Comparative Failures of Legal Education, 6 Clinical L. Rev. 401, 401-02, nn. 1-6 (2000).

43 Julian Beinart, et al, Architecture Education Study, vols. I and II (Consortium of East Coast Schools of Architecture 1981). 
consider the design studio "a paradigmatic model for future education in other professions." 44

In an individual critique-called a desk crit-a teacher responds to the work on the student's drawing board with "graphic and verbal advice." ${ }^{45}$ A teacher gives graphic advice by drawing. Communication between teacher and student is partly through words and partly through drawn images, "the teacher sitting with a single student for fifteen minutes to one hour engaged in an often silent dialog of pencil lines and fragmentary sketches." 46 Group crits and juries do not involve dialog and can be harmful for lack of it. After completing a project, a number of students display their work for judgment by a studio teacher or a respected practicing architect or, if a jury, several reviewers. ${ }^{47}$ "A student publicly presents his or her project by describing the drawings and models on view, then remains before the group to accept criticism."48

Interspersed in this process is the charrette, an intensely focusednearly around-the-clock-period of design before a deadline, typically preceding a group crit or jury review. "The test is to see how many consecutive nights one can work without sleep. It is not uncommon to be 'on charrette' (the American bastardization of 'en charrette') for a week, culminating in two or even three all-nighters." 49

Although the cultures of both architectural education and legal education can damage students' mental health, the accreditor for architecture schools has addressed the problem while the accreditor for law schools has ignored it. Complaints about the deforming atmosphere of many design studios have led the National Architectural Accrediting Board, the accrediting authority for architecture schools, to require architecture schools to develop policies intended to create a healthy studio culture. ${ }^{50}$ Among law students, many studies have shown that depression and other conditions related to stress and anxiety begin during the first year and increase afterward. ${ }^{51}$ But the American Bar Association's law

44 Noam Austerlitz, Iris Aravot \& Aaron Ben-Ze'ev, Emotional Phenomena and the Student-Instructor Relationships, 60 Landscape \& Urban Planning 105, 105 (2002).

45 Cuff, supra note 32, at 122.

46 James Polshek, quoted at Cuff, supra note 32, at 65.

47 Cuff, supra note 32, at 122.

48 Id. at 126. See Boyer \& Mitgang, supra note 33, at 25, 126-27.

49 Cuff, supra note 32 , at 126-28.

50 National Architectural Accrediting Board, 2009 Conditions for Accreditation, Condition I.1.2.

51 See e.g. Lawrence S. Krieger, Psychological Insights: Why Our Students and Graduates Suffer, and What We Might Do About It. 1 J. ALWD 259 (2002); Ruth Ann McKinney, Depression and Anxiety in Law Students: Are We Part of the Problem and Can We Be Part of the Solution? 8 Legal Writing 229 (2002); Kennon M. Sheldon \& Lawrence S. Krieger, Understanding the Negative Effects of Legal Education on Law Students: A Longitudinal Test of Self-Determination Theory, 33 Personality \& Soc. Psychology Bull. 883 (2007); Kennon M. Sheldon \& Lawrence S. Krieger, Does Legal Education Have Undermining Effects on Law Students? Evaluating Changes in Values, Motivation and Well-Being, 22 Behavioral Sci. \& L. 261 (2004). 
school accreditation standards ${ }^{52}$ impose no requirement comparable to the NAAB's on studio culture.

Architecture students long ago organized their own national union, the American Institute of Architecture Students, which has a paid staff and offices in Washington. Architecture students designated by AIAS serve on the NAAB bodies that develop accreditation standards. They participate in the meetings where new accreditation standards are considered-which is how the accreditation standard on studio culture was adopted. No law student, however, has ever served on the ABA Standards Review Committee, which drafts law school accreditation standards.

When an architecture school is inspected for accreditation compliance, one of the four members of the inspection team is a student from another school. But no law student has ever served on an ABA law school accreditation inspection team.

An architecture school is required to make publicly available its accreditation documents, which contain, among other things, evidence about how well (or badly) the school educates its students..$^{53}$ Law schools, however, aren't required to disclose accreditation documents to anybody, and the ABA treats those documents as secret. Consequently students have no way of finding out how schools spend their tuition money or whether it's effectively spent.

\section{Langdell}

Could you suggest a reason?

- Christopher Columbus Langdell

Although the Harvard Law School had enjoyed a good reputation under the influence of Joseph Story, who taught there while serving on the

52 See American Bar Association Section of Legal Education \& Admissions to the Bar, Standards for Approval of Law Schools (2011-2012). Accreditation standards are codes of rules, similar to statutes. Surprisingly, the architecture and medical accreditation standards are models of precision, clarity, conciseness, plain English, compositional grace, and talented drafting. The law school accreditation standards, however, have regrettably little of these characteristics. Compare the ABA Standards with the NAAB 2009 Conditions for Accreditation, the NAAB 2010 Procedures for Accreditation, and the Liaison Committee on Medical Education, Functions and Structure of a Medical School: Standards for Accreditation of Medical Education Programs Leading to the M.D. Degree (2012).

53 After the NAAB makes its accreditation review determination, an architecture school must disclose to the public its preinspection self-study, the inspection team's report to the NAAB, and other documents, including some with budgetary information. "These documents must be housed together in the architecture library and be freely accessible to all." NAAB, 2010 Procedures for Accreditation, $\$ 3.8$.a. "In order to promote transparency in the process of accreditation in architecture education, the program is required to make ... available to the public" a long list of documents with information showing how the school is run, including its finances. "These documents must be housed together and accessible to all. Programs are encouraged to make these documents available electronically from their websites." NAAB, 2009 Conditions for Accreditation, pt. II, $\$ 4.4$. 
Supreme Court, ${ }^{54}$ the school abruptly went into decline after Story died in 1845 , and it became a backwater. 55 "For a long time," the young Oliver Wendell Holmes wrote in the October 1870 issue of the American Law Review, "the condition of the Harvard Law School has been almost a disgrace to the Commonwealth of Massachusetts." 56

Christopher Columbus Langdell was born in 1826 to a New Hampshire farm family that quickly fell apart financially and emotionally. His mother died when he was seven. A brother drowned. The father, descending ever further into poverty, separated the three remaining children by sending them to live with different relatives. Somehow, Langdell scraped together the resources to attend Phillips Exeter Academy, a private college preparatory school. Daniel Webster had graduated from Exeter in 1796. Mark Zuckerberg, the founder of Facebook, graduated in 2002. Langdell graduated in 1848.

After studying briefly at Harvard College, teaching elementary school, and apprenticing in a law office, Langdell enrolled in the Harvard Law School in 1851 and graduated in 1854 . The course of study was typically completed in a year or two. Langdell took longer not because he was in academic difficulty, but because he had a job in the library, ${ }^{57}$ which foretold much about him and the future of legal education. School life and libraries defined Langdell, but in 1854 there was no employment for him in either. From then until 1870, he practiced law in Manhattan, where his experience seems primarily to have been writing briefs and reading. In February 1870, he returned to the Law School to teach and seven months later became dean because nobody else wanted the job. ${ }^{58}$

Unlike Osler, who has been unanimously admired in medical education, Langdell has been alternately revered and reviled. Former students wrote about him affectionately. Although much of what he did was opposed at the time, many in his generation and the one that followed considered him a pioneer who transformed legal education for the better. The reviling started in the 1920 s and continues today. He has been called "a brilliant neurotic" (by Jerome Frank) 59 whose teaching amounted to "indoctrination by brainwashing" (according to Grant Gilmore). ${ }^{60}$

54 Charles R. McManis, The History of First Century American Legal Education: A Revisionist Perspective, 59 Wash. U. L.Q. 587, 628-32 (1981-1982).

55 Id. at $630-31$.

565 Am. L. Rev. 177 (1870-1871).

57 William Schofield, Christopher Columbus Langdell, 55 AMER. L. Reg. 273, 292 (1907).
58 See Robert Stevens, Law School: Legal Education in America from the 1850's to the 1980's 36 (1983); Arthur E. Sutherland, The Law at Harvard: A History of Ideas and Men 162 (1967); see also II Charles Warren, History of the Harvard Law School 360-63 (1970; orig. 1908).

59 lerome Frank, A Plea for Lawyer-Schools, 56 Yale L.J. 1303, 1303 (1947).

60 Grant Gilmore, The Death of Contract 13 (1974). 
Legal realists objected to him as a self-deluded formalist who naively and rigidly believed that the law in books was the same as law experienced in real life. Although there was something to this criticism, it was overblown. For the realists, the lightening rods were statements like these: "Law, considered as a science, consists of certain principles or doctrines" (from the preface to Langdell's first casebook) ${ }^{61}$ and "if law be not a science, a university will best consult its own dignity in declining to teach it" (from his speech on the 250th anniversary of Harvard University's founding) ${ }^{62}$ But the realists misunderstood how the word science was used in the second half of the nineteenth century. And they misunderstood the context in which Langdell wrote.

Langdell didn't mean a science in the sense of astronomy or physics. In his century, a science was anything important and complex enough to be worth researching, especially if it included concepts that could be discovered and categorized. We still encounter that meaning. It's why our study of polities and governments is called political science, one of the social sciences, and it is why one of our popular songs could be titled She Blinded Me With Science. ${ }^{63}$ All Langdell meant was that law is constituted of rules and policies ("principles or doctrines") that could be discovered and categorized. ${ }^{64}$ Story had used the same word in the same way. ${ }^{65}$

In 1870 the principles or doctrines still needed to be catalogued and classified. Law was a mess. A legislative code was a rarity. The common law could not routinely be researched because there were no West reporters, ${ }^{66}$ no regional digests or other ways of finding cases, and no Shepard's or similar method of learning whether a case was still good law. On any given common law point, nobody could know what the "majority rule" or the "emerging trend" was. The big picture was unseeable. All the everyday lawyer could know was that Blackstone had claimed that a certain rule was part of the English common law or that in a given case, which the lawyer might fortunately have heard about, a local court had enforced a similar rule, or something like it, or something different. Even

61 C.C. Langdell, $A$ Selection of Cases on the Law of Contracts vi (1871).

62 Quoted by Sutherland, supra note 58, at 175.

63 Thomas Dolby, She Blinded Me With Science (Capitol Records 1982).

64 Stevens, supra note 58 , at 52.

65 For example, from Story's inaugural speech as Dane Professor of Law at Harvard (the chair to which Langdell was appointed in 1870): "I know not if among human sciences there is any one which requires such various qualifications and extensive attainments as the law ... [T] [he law is a science, in which there is no substitute for diligence and labour." Joseph Story, A Discourse Pronounced upon the Inauguration of the Author, as Dane Professor of Law in Harvard University (1829). See also William P. LaPiana, Logic and Experience: The Origin of Modern American Legal Education 29 (1994).

66 Reporters had existed for a long time, but before West, each reporter was limited to the state in which it was published and was generally unavailable elsewhere. 
reading a case could be baffling. Opinions were often written in an interminable formlessness that approached stream-of-consciousness, with little more structure than Molly Bloom's soliloquy at the end of Joyce's Ulysses.

The realist equivalent to Langdell's "science" remark is Karl Llewellyn's statement that law is "what officials do about disputes." ${ }^{67}$ Llewellyn was right, but, in the context of Langdell's time, so was he. Langdell had plenty of work discovering and categorizing the legal rules aspect of what judicial officials do about disputes. It might be too much to expect that he would have gone further to investigate what police officers, customs agents, and other executive branch officials do together with the psychological, sociological, and economic explanations for what judges or other officials do. Langdell had no access to psychology, sociology, or economics. They had not yet taken their modern forms.

Langdell's first full year of teaching coincided with his first year as dean. The deanship was at first a triviality with little or no inherent power. His immediate effect was as an innovative teacher. He soon became a willful and stubborn dean, although he never engaged in self-promotion or self-aggrandizement. As a teacher and as a dean, he left legal education with the eight Langdellian characteristics described here.

\section{A. Teaching Socratically from a casebook}

On the first day of his first full academic year, in the fall of 1870 , Langdell walked into his Contracts class and started asking questions about cases. Here's the classic account:

The class ... opened their strange new pamphlets [containing cases].

The lecturer opened his.

"Mr. Fox, will you state the facts in the case of Payne v. Cave?"

Mr. Fox did his best with the facts of the case.

“Mr. Rawle, will you give the plaintiff's argument?"

Mr. Rawle gave what he could of the plaintiff's argument.

"Mr. Adams, do you agree with that?"68

This and Langdell's other classes over the next few days "were followed by impromptu indignation meetings." 69 Expecting to be told the law rather than the reverse, students, according to one of them, "could see nothing in 
his system but mental confusion and social humiliation." ${ }^{70}$ All but seven stopped coming to class. ${ }^{71} \mathrm{~A}$ barrage of complaints followed from all directions, including alumni and other teachers. ${ }^{72}$ Hearing of this, Charles Eliot summoned students to his office and asked what they thought about Langdell-a startling situation in which a university president was asking first-year students to report on their teacher. Eliot decided not to intervene. Langdell, with stubbornness and courage, persisted.

A former student remembered him as "a modest, learned, and kindly man"73 who could become enveloped in discoveries in any subject he taught. His teaching style was both gentle and genteel, and he seems to have had a placid, uninspiring, and unfocused classroom presence. The same student recalled that he and his colleagues "learned that any position [we] might advance was pretty soon followed by the question, 'Could you suggest a reason?"74 Langdell asked it so often that the words "Could you suggest a reason?" became, among two generations of students, his trademark. ${ }^{75}$ Asking students for their thoughts can, in the right circumstances, be seen as a form of intellectual respect, and the students who took it that way-a tiny group at the beginning but many more in succeeding years-became devoted to him. ${ }^{76}$ The classroom tyrants came later. When they asked for a reason, it was not charming.

A true Socratic dialog-as Plato portrayed it-is made up of an elenchus, in which questions reveal the student's ignorance; an aporia, the point at which the student recognizes the ignorance; and a psychagogia, in which questions help the student come to insights that replace the ignorance shown earlier. ${ }^{77}$ The paradigmatic Socratic dialogue appears in the Meno, where Socrates interrogates a servant boy. During the elenchus, the boy recognizes the falsity of his own belief that the area of a square can

\section{$70 \mathrm{ld}$.}

71 Warren, supra note 58, at 373. A former student's account is at Franklin G. Fessenden, The Rebirth of the Harvard Law School, 33 Harv. L. Rev. 493 (1920).

72 Bruce A. Kimball, Christopher Columbus Langdell: The Case of an Abomination in Teaching Practice, NEA Higher Educ. J., Summer 2004, at 23, 31-32.

73 Schofield, supra note 57 , at 274.

$74 \mathrm{Id}$. at 275.

75 Id.

76 Joel Seligman, The High Citadel: The Influence of the Harvard Law School 32-35 (1978); Stevens, supra note 58, at 52-55 (1983); Warren, supra note 58, at 372-74. Anthony Chase, The Birth of the Modern Law School, 23 Am. J. Leg. Hist. 330 (1979); James M. Dente, A Century of the Case Method: An Apologia, 50 Wash. L. Rev. 93 (1974); William C. Heffernan, Not Socrates, But Protagoras: The Sophistic Basis of Legal Education 29 Buff. L. Rev. 399 (1980); Bruce A. Kimball, Students' Choices and Experience during the Transition to Competitive Academic Achievement at Harvard Law School, 1876-1882, 55 J. Leg. Educ. 163, 164 (2005) (hereinafter, Kimball, Students' Choices).

77 See Richard Robinson, Plato's Earlier Dialectic 7 (1941); Henry Teloh, Socratic Education in Plato's Early Dialogues 22 (1986); Heffernan, supra note 76, at 415. 
be doubled by doubling the length of its sides. And during the psychagogia, with a few hints from Socrates, he develops a mathematically correct method of doubling a square.

If a teacher conducts only an elenchus culminating in an aporia and at that point ends the dialog, the student can be embarrassed and perhaps humiliated, even if the teacher has a soft and unthreatening demeanor. Without that demeanor, the effect is brutal. Stopping at the aporia might have some precedent in the early Platonic dialogs, where Socrates "never talks to anyone without refuting him."78 In some of those dialogs, the elenchus "involved persistent hypocrisy; it showed a negative and destructive spirit; [and] it caused pain to its victims." ${ }^{79}$ But in the later dialogs, written by a more mature Plato, the psychagogia becomes more fully developed. Unless the person being interrogated argues belligerently, Socrates' questioning during the elenchus is encouraging, not demeaning, and the psychagogia ends with a sense of accomplishment on both sides.

No one knows whether Langdell actually questioned as Socrates did or instead asked aimless questions, wandering without any conversational structure. Langdell had a classical or at least semi-classical education and thought students ought not be admitted to law school unless, among things, they could read Latin without a dictionary. He must have known the dialogs, might have had some experience with them in the original Greek, and probably was influenced by them. But we cannot know, from the evidence available, whether he practiced the full model, complete with a satisfying psychagogia. All we do know is that former students who published their recollections thought they had learned and not been abused. Those who felt otherwise-in a Victorian and Anglo-Saxon culture allergic to unpleasantness-might have avoided saying so in print.

Langdell spent prodigious amounts of time with his case law obsession, "ponderously extracting every possible legal principle from each case." 80 In a typical story, a former student recalled that Langdell changed his opinion in regard to a case three times in the course of one week, each time advancing with positiveness a new doctrine. That he could do this without losing the respect or confidence of his students shows the esteem in which he was held. They knew well he was a teacher of originality and great industry, with no object but to discover and state truly the principles of the law. ${ }^{81}$ 
In October of 1870, Langdell took an initial batch of his cases across the Charles River to an old-line Boston publisher, Little, Brown \& Co., and had them printed as the first casebook-or more accurately, half of the first casebook. ${ }^{82}$ The complete text was published the following year. ${ }^{83}$ It's the same size as a modern casebook but covers only three subjects: offer and acceptance (163 pages), consideration (296 pages), and conditions (546 pages).

Dozens of cases follow each other without offering the slightest clue as to why any of them is in the book. For example, 41 cases on conditions precedent fill 172 pages and are not organized around ideas but instead appear in nearly chronological order, from Anonymous, a one-paragraph Kings Bench case decided in 1500, to Raymond v. Minton, an Exchequer case from 1866. Cases seem to be included for no better reason than that Langdell thought them interesting. In a modern Contracts class, the book would be unuseable.

This proto-casebook corroborates what students said of Langdell's teaching during the early stages of his faculty career: he brought his curiosity into the classroom and shared it. He asked questions so that students would discuss with him the things about which he was curious. If instead he had taught entirely by making statements about the law (lecturing), students would have said nothing. He would have been bored, having deprived himself of conversation. Students, too, would have been bored, sitting silently and passively. Those who preferred the safety of bored silence hated Langdell. But those who wanted more were energized by the opportunity to share his curiosity and participate in his thinking.

This classroom conversation reflected Langdell's personality, which was hermetically sealed. None of the accounts published by his contemporaries identifies anyone as a long-term close friend of the adult Langdell - a genuinely intimate friend as distinct from a colleague or a friendly acquaintance. He did not socialize for the pleasure of it, or much at all. He mentored James Barr Ames, who later succeeded him as dean, and the two were allies. But they were not personally close, and as the mentored one and 20 years younger than Langdell, Ames was always in the lesser position. As an adult, Langdell had almost no experience of family. He did not marry until $1880^{84}$ and had no children. The marriage is barely mentioned in accounts of Langdell's life and work. Bruce Kimball's Langdell biography discusses the marriage on only three of its 351 pages of

82 Bruce A. Kimball, The Inception of Modern Professional Education: C.C. Langdell, 1826-1906 87 (2009) (hereinafter Kimball, Inception).

83 Langdell, supra note 61. See Kimball, Inception, supra note 82, at 91.

84 The Centennial History of the Harvard Law School 1817-1917, at 236 (1918). 
text. The index lists six other pages where the marriage is mentioned in passing. We know more about the occupation of the wife's father (the minister in Langdell's church) than about her ${ }^{85}$ Kimball does provide her name (Margaret) and age when wed (24 years old, to the 54-year-old Langdell), ${ }^{86}$ information hardly available elsewhere except in primary sources. The age difference might have made it possible for Langdell to admit Margaret into his reclusive private life, as he generally found direct human connection uncomfortable. Published student recollections do not describe even a single out-of-class conversation in which Langdell showed a deep empathic interest in an individual student as a human being. The conversations he conducted in class suited him perfectly. They were limited to linear reasoning working from written analysis. They had no emotional content. All of the other participants were subservient because they were students. And he was in control because he asked questions that the other participants felt required to answer to his satisfaction. We do not know whether these conversations-among the most common he had during the 1870 - - relieved any of what must have been his loneliness.

No statute appears in Langdell's casebook, and he seems not to have thought statutes worth addressing in the classroom. Fact analysis was nearly precluded. His casebook, and nearly every other since, includes only the court's statement of its version of the facts and nothing from the evidentiary record, leaving no opportunity to critique a court's factual logic. In a course called Contracts, Langdell's casebook includes no contracts, but instead only cases about contracts. As a genre, casebooks are based on the idea that nearly all we can know about what happens in the law comes from litigation in the form of judicial opinions.

The Contracts course today still resembles the one Langdell taught. It has little relationship to contracts as they are understood by transactional lawyers. Of the dozen or so chestnut cases that appear in nearly all Contracts casebooks today, about half teach issues that rarely occur in the modern experience of lawyers and courts. ${ }^{87}$ "One can spend an entire career as a transactional lawyer... without ever seeing an offer,

85 See e.g. Stephen A. Siegel, John Chipman Gray and the Moral Basis of Classical Legal Thought, 86 lowa L. Rev. 1513, 1578 n. 437 (2001).

86 Kimball, Inception, supra note 82, at 250.

87 For example, Dickinson v. Dodds, 2 Ch. Div. 463 (Ct. App., Chancery Div. 1876) (an offeror's behavior incompatible with the offer is revocation of the offer once the offeree has learned of it); Hamer v. Sidway, 57 N.E. 256 (N.Y. 1891) (the consideration requirement can be met even though the performance of a promise would benefit the promisor as well as the promisee); Raffles v. Wichelhaus, 159 Eng. Rep. 375 (Ct. Exchequer 1864) (a contract is voidable for misunderstanding between the parties at to the meaning of a key term); Peevyhouse v. Garland Coal E Mining Co., 382 P.2d 109 (Okla. 1962) (a court will not grant a remedy that amounts to economic waste); Rockingham County v. Luten Bridge Co., 35 F.2d 301 (4th Cir. 1929) (damages are not available to compensate for performance that occurs after the other party's wrongful repudiation), Wood v. Lucy, Lady Duff Gordon, 118 N.E. 214 (N.Y. 1917) (consideration can be implied even if not expressed by the parties). 
acceptance, or consideration case." ${ }^{88}$ The Contracts course "is not a course in contracts." 89

Lawyers do not typically help their clients commit torts or crimes. Lawyers do, however, help clients create contracts. But Contracts students learn so little about how to interpret a contract that they might be speechless if a client were to ask them what a particular provision means. Students do not study the internal logic of a contract; the permeating effect of standards and qualifications; the difference between a legal provision and a business provision; the differences in how covenants and conditions incentivize behavior; the effect of a contract's assignability on its value; the comparative risk allocation efficiency of conditions, representations, and warranties; the reasons for obtaining simultaneous representations and warranties; the ways in which representations blend tort law and contract law; the reasons why parties almost always ignore remedies law when resolving disputes between themselves; or any of the other basic concepts needed to comprehend what a contract does and how it does it. Contracts students don't even read contracts, but instead only snippets quoted in cases. They study only what Langdell considered interesting-judicial opinions that clean up the debris in the exceedingly rare instances of a contract's entering a courtroom.

It may be that teaching the analytical process was never Langdell's goal, but instead an accidental byproduct of his simple curiosity about cases, which he brought into the classroom. There was and still is something remarkable about a teacher who keeps changing his mind while teaching, in ways plainly obvious to students. As he aged, Langdell gradually stopped asking classroom questions, and eventually he just explained the cases in class. ${ }^{90} \mathrm{He}$ abandoned Socratic questioning but not the case method or the casebook. ${ }^{91}$ Students do not, however, learn legal analysis simply by reading cases. They learn it through requirements to explicate. Langdell didn't do that the thorough way, by critiquing a student's written analysis as in a modern legal writing course. He did it the short way, orally in class through questions. And he stopped doing even that when he stopped asking questions.

88 Edward Rubin, What's Wrong with Langdell's Method, and What to Do About It, 60 Vand. L. Rev. 609, 641 (2007).

89 Edward Rubin, Why Law Schools Do Not Teach Contracts and What Socioeconomics Can Do About It 41 San Diego L. Rev. 55,55 (2004).

90 William Schofield, quoted at Warren, supra note 58 , at 458 .

91 Kimball, Students' Choices, supra note 76, at 176. 


\section{B. The required curriculum}

Beginning with the $1871-1872$ academic year, Harvard's required courses became-at Langdell's insistence-Contracts, Torts, Civil Procedure, Real Property, Criminal Law, Evidence, and Equity. ${ }^{92}$ This is remarkably close to the required curriculum at most law schools today.

As equity merged with law, the course by that name disappeared, and what students needed to know about equity was absorbed into Civil Procedure and Contracts. Evidence is still taken by the overwhelming majority of students even though it's not usually required today. After the federal government grew to its present role during the first half of the twentieth century, Constitutional Law became a required course everywhere. The courses in Legal Writing and Professional Responsibility also became required.

With only these variations, the required curriculum at nearly all law schools today isn't significantly different from what Langdell believed in 1871 it should be at Harvard-"before the Internet, . . . before the telephone; not just before man reached the moon, but before he reached the North Pole; not just before Foucault, but before Freud; not just before Brown v. Board of Education, but before Plessy v. Ferguson." "93 Just as the world has changed, law-creation has changed as well. By the end of the New Deal, legislatures had mostly taken over the business of lawmaking, relegating courts to a secondary role. But even today, 140 years after Langdell's first Socratic class, the required curriculum, built on casebooks, still reflects a nineteenth-century view of law and how it's made. "American legal education has been an astonishingly stable cultural practice." 94

\section{The essay examination}

Before 1870, degrees were awarded on the basis of attendance alone. In that year, Harvard University, at Eliot's insistence, began requiring examinations as a condition to graduate from any of the University's schools or departments. ${ }^{95}$ The first law school examinations were given in the spring of $1871 .{ }^{96}$ As everywhere else in higher education of that era, the 1871 exams (except Langdell's) asked pure knowledge questions, such as these from the course on Property: ${ }^{97}$

92 Seligman, supra note 76, at 33.

93 Todd D. Rakoff \& Martha Minow, A Case for Another Case Method, 60 Vand. L. Rev. 597, 597 (2007).

94 ld.

95 Kimball, Inception, supra note 82, at 161 .

96 ld. 
What is meant by estate as applied to land? What are the different kinds of estate? Give examples of each.

Define a tenancy in severalty, a joint tenancy, and a tenancy in common. What are the incidents of joint tenancies and tenancies in common? How may they be severed by acts of the parties or by acts of law?

To answer, a student needed only to recite memorized law. No exam (other than Langdell's) required students to resolve legal issues embedded in a fact pattern. Langdell's Contracts exam consisted of 15 questions like this:

If you send an offer to New York to-day and to-morrow you write again withdrawing the offer, and your second letter reaches your correspondent before your offer is accepted, at what point of time is the revocation of the offer complete, and why?

Later Langdell asked more complicated questions, like this one from his 1875 exam:
$A$, in Boston, writes to $\mathrm{X}, \mathrm{Y}$, and $\mathrm{Z}$, in Concord, offering $\mathrm{X}$ a certain estate at a certain price, offering $Y$ a certain horse then in Y's stable, and offering $\mathrm{Z}$ a certain mare then in $\mathrm{Z}$ 's stable. $\mathrm{X}$ and $\mathrm{Y}$ reply according to A's request, by return mail, accepting their respective offers. $Z$, according to A's request, deposited the purchase money for the mare with A's banker in Concord. A dies before receiving any intelligence of the acceptance of his offer. Were any contracts, unilateral or bilateral, made, or not, and why?

During the twentieth century, the typical law school exam everywhere became a smaller number of larger essay questions. Langdell's version, however, is beautifully concise, raising several issues per question in a few, tightly constructed sentences.

No empirical evidence proves that these exams, or any other exams given in law schools, accurately measure student learning. No study based on rigorous methodology has evaluated law school exams to determine whether they validly and reliably measure what they purport to measure. No attempt to do so has been published, and social science would not consider the proposition proved without replication studies conducted

97 All the examples are from the Harvard University Library website: http://oasis.lib.harvard.edu/oasis/deliver/ deepLink?_collection=oasis\&uniqueId=law00237. Spelling is as in the original. See also Steve Sheppard, An Early Informal History of How Law Schools Evaluate Students, with a Predictable Emphasis on Law School Final Exams, 65 UMKC L. Rev. 657,705 (1997). 
with different methodologies on different subject populations. The traditional exam's structure seems to have evolved for reasons irrelevant to accurate measurement. Three-hour exams are administratively convenient, one exam in the morning and another in the afternoon, with time in between to clear away the morning's debris, break for lunch, and set up for the afternoon, completing everything by the end of the business day. Traditionally that three-hour exam has included three essay questions. No one knows why, except for the symmetry.

Langdell's exam, together with his classroom method, may have caused substantial numbers of students to leave Harvard. Mere memorization was insufficient for his exams, and he was a tougher grader than his colleagues (until James Barr Ames was hired and matched Langdell in this respect). ${ }^{98}$ Students could not escape Langdell. Except for Ames, he was the only Harvard Contracts teacher and in many years the only Civil Procedure teacher as well. One hundred and sixty-five new law students enrolled in the fall of 1870 , Langdell's first full year of teaching. ${ }^{99}$ Only 45 of them took the exams administered in June 1871, and only 37 passed. In the following year, 92 new students entered the school, 26 took the exams, and 19 passed. ${ }^{100}$ The most immediate contributing factor in regaining respect for the school may have been driving away so many intellectually passive students.

\section{The library as the center of the law school}

As a student and as a teacher, Langdell's attachment to books and libraries seemed so guileless as to be endearing (although finding meaning in cases is hardly a cosmopolitan intellectual life). The stories of the young Langdell sleeping overnight on library tables might or might not have been true. But eventually he caused the library to be converted "from a textbook dispensary to a scholarly resource." 101 In Langdell's time, it was scholarly only as a repository for case law, which was beginning to be compiled into searchable commercial reporters. (John B. West started the West Publishing Company in 1872.) Still, Langdell was able to call his law library "the proper workshop of professors and students alike ... it is to us what the laboratories of the university are to the chemists and physicists." ${ }^{102}$ In modern legal education, even with the Internet, the

98 Kimball, Inception, supra note 82, at 210-213.

99 ld. at 214 .

$100 \mathrm{ld}$.

101 Kimball, Students' Choices, supra note 76, at 165.

102 Christopher Columbus Langdell, Harvard Celebration Speeches, 3 Law Q. Rev. 123 (1887). 
library is still the largest and most obvious part of any law school's building.

Law schools are the only form of professional education centered around libraries. Medicine has produced a vast published literature reporting empirical research on the causes and treatments of disease. But medical schools have not been built around their libraries or even their laboratories. The most obvious feature of a medical school is its teaching hospital, and in an architecture school, its design studio. Faculties in other professions would naturally assume by analogy that a law school is centered around its own law firm. Every law school owns a law firm, and some own several. But these firms-clinics-are typically marginalized in resources and role.

\section{E. The requirement of seven years of higher education for a law degree}

This is really two requirements. One is three years of study to obtain a law degree. The other is the prerequisite of four years of undergraduate study to enter law school.

When Langdell was appointed in 1870, the school was "a two-year operation, at best, with students free to start at any point." ${ }^{103}$ By 1876, it had grown to three years, although graduating sooner was possible, and by 1899 the degree was standardized at three years. ${ }^{104}$ Since then, only the degree's name has changed, from a bachelor of laws (LL.B.) to a juris doctorate (J.D.). The three-year J.D. is essentially equivalent to the fouryear M.D. minus the year on the wards. In both law and medicine, the first two years cover fundamental knowledge, and the last year is a mixture of specialization and professional skills. But medical education inserts an additional year between the first two and the last one. That year-the year on the wards with patients-is the heart of what Osler provided, and for which there is no Langdellian equivalent.

In 1875, Langdell began requiring that prospective students, as a condition of admission, either have a bachelor's degree or pass an examination testing, among other things, knowledge of Blackstone and the ability to translate without a dictionary from Virgil, Cicero, and Caesar. ${ }^{105}$ The university Board of Overseers ordered this rescinded. ${ }^{106}$ It was readopted in 1895, and the examination option was dropped in 1909.107

103 Stevens, supra note 58 , at 36 .

104 Seligman, supra note 76, at 39; Stevens, supra note 58, at 37; Kimball, Students' Choices, supra note 76, at 164. See Langdell, supra note 61, at 124.
105 Seligman, supra note 76 , at 38 .

$106 \mathrm{Id}$. at 39.

107 Id. at 41-42. See Langdell, supra note 61, at 124. 
Langdell himself did not have a bachelor's degree, although he almost certainly would have passed the examination.

These seven years add up to the longest period of pre-bar education anywhere in the world. England and France require a total of five years of schooling; Canada requires six; and other industrialized nations fit within that range. But the additional education required in the United States is not in the study of law. It is in non-law undergraduate subjects preceding law school. It also represents an extraordinary burden on students, both in the obvious tuition expense, including the interest paid to borrow tuition money, and in the hidden opportunity costs associated with foreshortening an income-producing career by one or two years.

The lost years aren't early, low-income ones. They're the final years of a career-the ones that typically produce the highest income. Income at any point during a career correlates to the number of years since graduation, and not to the lawyer's age. But people retire based on their age, not their graduation date. Graduating a year or two later thus subtracts time at the end of a career, not the beginning. Because the opportunity costs culminate decades after their cause, they aren't noticed by students or by lawyers-or even by law faculty, whose own careers have been foreshortened in the same way.

The current crisis in law schools-precipitated by a widening perception that a law degree is a poor investment in light of predicted professional employment and income-was not caused by the three-year cost of legal education, which is undeniably necessary for entry into a profession. It was caused by an entirely different burden: the uniquely American law school admissions requirement of a bachelor's degree.

That burden became widespread not because seven years are necessary to produce a lawyer, but because of the American experience of immigration, which triggered antisemitism and other bigotries early in the twentieth century. The admissions requirement of a four-year bachelor's degree spread across legal education to prevent "Jews, immigrants, and city-dwellers" from "undermin[ing] the American way of life" through the legal profession. ${ }^{108}$ Four years of college were thought necessary to Americanize those who were neither white nor Anglo-Saxon nor protestant. ${ }^{109}$ In 1923, the dean of the Yale Law School took the position that a student whose parents were born abroad should attend college longer than others as a condition to admission to a law school. ${ }^{110} \mathrm{He}$ also argued that undergraduate grades should not be used as an admissions 
criterion because intellectual ability mattered less than the social and ethical superiority of established American families. ${ }^{111}$ Robert Stevens has pointed out that "wherever one looks in the literature of the period, the establishment expressed concern about the background of those who were alleged to be demeaning the bar." 112 That would include almost everyone who was not born into a well-financed family. In 1920, only $3.3 \%$ of the U.S. population had four or more years of college. ${ }^{13}$

Langdell probably did not share these motivations. In 1875 , when he first tried to impose pre-admissions educational requirements, the overwhelming majority of immigrants arrived from countries that were white, predominantly protestant, and either Anglo-Saxon or not far from it: Britain, Germany, and Scandinavia. Significant immigration from Eastern and Southern Europe did not begin until the last decade of the nineteenth century, and it did not become a flood, panicking nativists, until after 1900. Despite his own family's background, Langdell had overcome the financial odds and gone to college. His elitism was intellectual. He preferred to be surrounded with men (women were not permitted) who had read Virgil in Latin (common in that era among college graduates) than with those whose experience in life had been more practical. That was certainly consistent with his feelings about the legal profession itself.

\section{F. A faculty divorced from practice}

When Langdell and Eliot appointed James Barr Ames to the faculty in 1873, they hired the first American law professor who had never practiced law. ${ }^{114}$ For Langdell, who had fled practice, hiring a teacher who had never practiced at all seemed congenial. It was also the beginning of insularity, as Ames had the additional virtue of having just graduated from Langdell's Harvard and having been Langdell's student as well. Harvard did not immediately switch to hiring teachers like Ames exclusively. The progression was more erratic. James Bradley Thayer and John Chipman Gray later joined the faculty on the strength of their accomplishments in the profession. But eventually Ames became the model for a faculty with little practice experience, or even none.

Within his first two years of teaching, Ames compiled casebooks on torts and civil procedure. ${ }^{115}$ Eventually he published a total of nine casebooks. ${ }^{116} \mathrm{He}$ taught "Langdell's case method more effectively than

113 U.S. Census Bureau, 2012 Statistical Abstract, Table HS-22.
114 Kimball, Students' Choices, supra note 76, at 165. See Stevens, supra note 58 , at 38 ; Sutherland, supra note 58 , at 164.

115 Kimball, Students' Choices, supra note 76, at 176.

116 Stevens, supra note 58 , at 56. 
Langdell" did. ${ }^{117}$ When Langdell retired from the deanship in 1895, Ames succeeded him. ${ }^{118}$

Today, a substantial record as a top-notch lawyer is practically disqualifying for a casebook teaching job. In fact, an applicant seeking tenure-track faculty employment might become more attractive by never practicing law at all and instead obtaining a Ph.D., or at least an appropriate LL.M. This represents the opposite of the Oslerian ideal-a faculty member who is simultaneously a first-rate teacher, researcher, and practitioner. Langdell's idea was not just a divorce from practice; it was disdain for it as well. Today, the word disdain and its synonyms occur over and over again in articles that critique the law professoriate's view of practice. ${ }^{119}$

Ames himself wrote that "Langdell did not often appear in court, and, leading a secluded life, was not generally known even by lawyers." ${ }^{120}$ It's a myth, though commonly believed, that Langdell never had a client and never stood before a judge in a courtroom. ${ }^{121}$ But Langdell disliked the practice of law, thought it a lesser form of intellectual activity, had little direct experience with clients or courts, ${ }^{122}$ and apparently believed that the only part of lawyering worth teaching was reading case law and developing theories and arguments based on what he had read. Case law-based theorizing and argumentation did not fill a lawyer's day then and do not today. They are a small proportion of the skills needed for capable lawyering. But of the tasks Langdell had to do while practicing law, they are the only ones he found truly interesting. Becoming a teacher allowed him to leave everything else behind.

If Osler had been in law rather than medicine, Langdell would not have hired him. "What qualifies a person ... to teach law," said Langdell,

117 Seligman, supra note 76 , at 37 .

$118 \mathrm{Id}$. at 42,55 .

119 Amy B. Cohen, The Dangers of the Ivory Tower: The Obligation of Law Professors to Engage in the Practice of Law, 50 Loy. L. Rev. 623, 632 (2004) ("the apparent disdain many professors feel and perhaps even express towards practice and practitioners"); Harry T. Edwards, The Growing Disjunction Between Legal Education and the Legal Profession, 91 Mich. L. Rev. 34, 37 (1992) ("law professors hired from graduate schools, wholly lacking in legal experience or training, who use the law school as a bully pulpit from which to pour scorn upon the legal profession") (Edwards has served on the D.C. Circuit bench since 1980; in the ten years before that, he taught at Michigan and Harvard.); Wayne S. Hyatt, A Lawyer's Lament: Law Schools and the Profession of Law, 60 Vand. L, Rev. 385, 387 (2007) ("disdain both for the practice of law and for those of us who practice"); Brent E. Newton, Preaching What They Don't Practice: Why Law Faculties' Preoccupation with Impractical Scholarship and Devaluation of Practical Competencies Obstruct Reform in the Legal Academy, 62 S.C. L. Rev. 105, 127 (2010) ("disdain for practitioners and judges among some full-time faculty members"); Robert P. Schwerk, The Law Professor as Fiduciary: What Duties Do We Owe to Our Students?, 45 S. Tex. L. Rev. 753, 767 (2004) ("Many law professors do not like the practice of law".).

120 James Barr Ames, Christopher Columbus Langdell, 1826-1906 in 8 Great American Lawyers 465, 473-474 (William D. Lewis ed. 1909).

121 Bruce A. Kimball \& R. Blake Brown, "The Highest Legal Ability in the Nation": Langdell on Wall Street, 1855-1870, 29 Law \& Soc. Inquiry 39 (2004).

122 Seligman, supra note 76 , at 31 ; Warren, supra note 58 , at 360. 
"is not experience in the work of a lawyer's office, not experience in dealing with men, not experience in the trial or argument of cases, not experience, in short, in using law, but experience in learning law." ${ }^{123}$ Eliot, who as president of Harvard knew Langdell's views on faculty hiring, attributed to him the belief that "success at the Bar or on the Bench was, in all probability, a disqualification for the functions of a professor of law."124

And if Langdell had been in medicine, Osler would not have hired him. A physician who disliked the practice of medicine would have been an incompetent bedside teacher and dangerous on the wards. For Osler, the patient was the real textbook, and today the patient is still the center of attention in the medical education that Osler and his colleagues created. In Langdell's legal education, the client was entirely absent even though the core of a lawyer's work is understanding the client, counseling the client, and solving problems as the client wishes them solved. Even today, she is at most a bystander, discussed infrequently if at all, except in clinics and other skills courses.

\section{G. Entrusting the professoriate's literature to students}

The Harvard Law Review was not the first student-edited law review, but it was the first to survive, ${ }^{125}$ and it set the mold, in format, in operation, and in its role in the law school. In 1886, Harvard students began editing and publishing the Review ${ }^{126}$ after enlisting Ames's support. Although Langdell was dean at the time, he seems not to have been directly involved, at least at first. ${ }^{127}$ But a student-edited law review is a natural consequence of the casebook classroom. If students are to discover the law for themselves in class, with the teacher supplying the questions, it would not be surprising for them to continue that work in an extracurricular publication. In fact, in their first issue the student editors declared one of their purposes to be providing "some idea of what is done under the Harvard system of instruction."

In no other field are scholarly journals edited by students. Elsewhere in higher education, editing is done entirely by faculty, and editing a scholarly journal is considered a greater contribution to the field than publishing an article in it. In medicine, the idea of allowing students to

123 Langdell, supra note 61, at 124.

124 Charles W. Eliot, Langdell and the Law School, 33 Harv. L. Rev. 518, 520 (1920) (italics added).

125 Michael I. Swygert \& Jon W. Bruce, The Historical Origins, Founding, and Early Development of Student-Edited Law Reviews, 36 Hastings L.J. 763 (1985). Earlier student-edited journals were published at Albany Law School and at Columbia, but they did not survive.

126 Seligman, supra note 76, at 40. See Swygert \& Bruce, supra note 125.

127 Swygert \& Bruce, supra note 125 , at 770-771. 
edit research journal articles would be considered irresponsible. With rare exceptions, however, law faculty do not involve themselves in journal editing, and a substantial amount of the professoriate's research and literature is controlled, uniquely in higher education, by students.

\section{H. The Langdellian bargain}

Langdell argued-and his university president, Charles Eliot, was persuaded-that masses of students could be taught law economically in large classes, and the result would be professional learning because students in a Socratic class would do more than passively receive information, as in a lecture. The only substantial investment in such an enterprise would be the library. Personnel costs would be low compared with revenue because of the large number of students in each teacher's classroom. Teaching would be so financially efficient that a profit could be generated each year. Eliot initially let Langdell keep the profit for law school use, but the bargain has evolved since then so that law school faculties and universities comfortably share the surplus.

Langdell and Eliot did not sit down and haggle until they agreed on this. They proceeded instead in small steps over many years, each supporting something the other had decided to do about some seemingly minor issue until they gradually settled into the arrangement that has governed legal education ever since. As Robert Stevens, an historian of legal education, put it, "President Eliot smiled on Langdell's Celtic wisdom in having invented the financially attractive case method system and Langdell, in return, purred." 28

These two were not concerned with administrative precedent. Almost none existed. Most lawyers were educated as Lincoln had been-by reading law while working, as an apprentice, in an older lawyer's office. The Jacksonian Era had left the country with a feeling that educated elites should not control professions and that law in particular should be accessible to anyone literate enough to memorize some Blackstone. The very few university law schools were, like Harvard's in 1870 , small departments with tiny full-time faculties. An elite lawyer in a cosmopolitan northeastern city might have attended a university law school, but as a substitute for a liberal arts education and to obtain a credential largely proving that the lawyer came from a family wealthy enough to support him as a gentleman student.

A law school's place in a university was not secure. In the nineteenth century, American higher education reshaped itself on the German model 
of a university as a source of knowledge that can be published and cataloged. Until Langdell, law faculties did little of that. As late as 1918, Veblen could speak for many in higher education when he wrote that a law school "belongs in the modern university no more than a school of fencing or dancing"; ${ }^{129}$ that casebook teachers "stand in a relation to their students analogous to that in which the 'coaches' stand to the athletes,"130 and that law draws on very little of the intellectual, as demonstrated by "the unscientific and unscholarly nature of the required training."131 For prestige purposes in higher education, preparing students for life, including the life of the mind, is less important--often much less important-than what the professoriate calls "the creation of knowledge."

Eliot was a chemist. Chemistry has always had a secure place in higher education as a source of publishable and catalogable knowledge. But chemistry cannot be learned without laboratory teaching. Langdell promised the law equivalent of laboratory learning, although today that more accurately fits clinics and legal writing courses than the casebook classroom. When a furor erupted over Langdell's first Socratic classes, Eliot understood that to be evidence of progress. A lesser university president might have told Langdell to stop making trouble.

Although Eliot let his law school keep its entire surplus revenue, later presidents throughout higher education gradually began to claim increasing amounts of it for uses elsewhere in their universities. Some of this is justified as sharing overhead costs. A modern law school, unlike Langdell's, uses university resources such as centralized computer systems and campus security. A modern university will take a specific percentage of its law school's operating revenue, which at most schools comes largely from tuition. It is not unusual for that percentage to equal one fifth to one quarter of the law school's operating revenue, vastly exceeding the law school's true share of overhead costs. In addition, the university typically will want a portion of the law school's fund-raising. Most law schools are thus operated by their universities as profit centers.

When a law school's faculty, or even its accreditor, ${ }^{132}$ asks to see detailed financial records showing how much of the university's share actually pays for the law school's overhead costs and how much is treated by the university as profit, the university's response rarely includes hard 
evidence that would clarify the matter. Typically, inquiries go no further because, even though universities now take out profit, the Langdellian bargain still satisfies law school faculties. A faculty is able to retain resources to pursue its scholarly interests, and although the faculty might want more, those resources, together with law faculty compensation, cause envy in other university departments.

Law faculties today still consider themselves bound by and benefitting from this bargain, even though a transcript of a contemporary doctrinal class would typically reveal much lecturing and little Socratic questioning (which would have disappointed Eliot). ${ }^{133}$ Among the benefits of the bargain to the faculty are leniency, compared with other parts of a university, in teaching requirements measured by the time needed to teach casebook courses, freeing up a substantial amount of faculty time for scholarship that is supported, for the most part, by tuition money. (In a medical school, research is paid for by the National Institutes of Health and by private corporations - and none of it by tuition.)

The Langdellian bargain settled the financial arrangements through which legal education would enter universities. Large numbers of students would be taught, with little capital investment, and in most years law school revenues would exceed expenses. That would provide resources for faculty to do scholarship on whatever subjects interest them. Those have been the expectations of university administrators and law school faculties for 140 years. Whenever change is proposed in legal education, the threshold question is whether it would be consistent with the Langdellian bargain. If the proposal would significantly reallocate resources-either within the law school or between the law school and the university-in a way that would alter the bargain, the proposal fails because no one will give up voluntarily what the bargain has provided.

The eight Langdellian characteristics weren't immediately adopted outside Harvard. But by the beginning of the twentieth century they were becoming essential at the elite law schools, and within a few decades after that, nearly all law schools either had adopted them or aspired to do so. Each feature added to legal education since then, such as skills education, has been treated as suspect. But the Langdellian characteristics are assumed to be normative, essential, immutable, and eternal.

133 See e.g. William M. Sullivan, Anne Colby, Judith Welch Wegner, Lloyd Bond \& Lee S. Shulman, Educating Lawyers: Preparation for the Profession of Law 64-73 (2007) (a report of the Carnegie Foundation for the Advancement of Teaching project on Preparation for the Professions) (hereinafter, Sullivan et al., Educating Lawyers); Thomas L. Shaffer \& Robert S. Redmount, Lawyers, Law Student and People 168 (1977) (contemporary law school teachers tend to ask questions in the classroom only as "a garnish to lecture" or as "a way to make lectures more palatable" and because of "an algebraic increase in cognitive information in all areas of the law and student demand for pure, clear information rather than exercises which are asserted to provide mental training"). 
After its Flexner Report, the Carnegie Foundation for the Advancement of Teaching commissioned Alfred Z. Reed to examine law schools. ${ }^{134}$ He produced two reports, one in $1921^{135}$ and another in 1928. ${ }^{136}$ The 1928 report observed that " $[t]$ here is probably no other practical calling the preparation for which is so unrelievedly academic as that which is provided for American lawyers by most American law schools," especially as compared to schools of medicine, architecture, dentistry, and engineering (and Reed did compare them). ${ }^{137}$ Flexner could see medical education with a fresh eye because he was not a doctor, and Reed was able to do the same with law schools because he was not lawtrained. ${ }^{138}$ Academic medicine embraced the Flexner Report and still does so today, a hundred years later, practically revering the insights and criticisms of an outsider. ${ }^{139}$ But legal education ignored the Reed reports, which influenced nothing. In 2007, Carnegie tried again with another report, ${ }^{140}$ which came to conclusions similar to Reed's.

\section{Coda}

The Parisian atelier might have been the gold standard of architectural education at the time, but it was also part of an underground. No atelier was affiliated with a university, and to study in one would have seemed risky to anybody who was not at heart an artist defiant of convention. Of the three venues-the design studio, the teaching hospital, and the law school classroom - the design studio is the one with by far the deepest history of creativity. It is the only one of the three where creativity and technical ability are equally valued and where creativity is the subject of constant discussion. Schön classified the design studio as one of the "deviant traditions of education for practice-traditions that stand outside or alongside the normative curricula." ${ }^{141} \mathrm{He}$ meant that as high praise.

What would have happened if Langdell-rather than Osler-had knocked on Walt Whitman's door? A safe guess is that Langdell would quickly have become tense in the chaotic home of a bizarre poet. It was not in Langdell's personality to enjoy people or anything else not found in

134 Stevens, supra note 58 , at 112 .

135 Alfred Z. Reed, Training for the Public Profession of the Law (1921).

136 Alfred Z. Reed, Present-Day Law Schools in the United States and Canada (1928).

137 Id. at 215.

138 Stevens, supra note 58 , at 112.

139 E.g., Cooke, et al, 100 Years, supra note 22.

140 Sullivan et al., Educating Lawyers, supra note 133, at 80-81, 186-88, 192-93.

141 Schön, Educating, supra note 41, at 15. 
published legal analysis. He was so uncomfortable dealing with strangers that when the Harvard Board of Overseers was deciding whether to approve his appointment to the faculty, he refused an invitation to share a meal with some of them ${ }^{142}$-a potentially self-destructive act. Meeting an author of emotionally charged verse would have unnerved him. We can imagine excuses being made by the visitor, followed by a hasty departure and a sigh of relief in the street outside. But for Osler, encountering Whitman and his clutter was fun. Osler's intellect absorbed everything and enjoyed doing it.

Osler authored "the first great textbook of modern medicine," which "dominated its market, had huge sales, [and] went through many editions." ${ }^{43}$ It was also "the last text in which a single author dared to write on the whole range of the body's internal ills." ${ }^{144}$ Unlike Langdell's casebook-which was used only by the few American teachers who taught Contracts according to the Langdellian method in the late nineteenth century-The Principles and Practice of Medicine "quickly became the dominant medical textbook in the English-speaking world."145 John Singer Sergeant painted Osler at the center of his group portrait The Four Doctors, with a globe behind his head and the picture's focal point the pen in Osler's hand. A biography ${ }^{146}$ published seven years after his death won a Pulitzer Prize solely because it was about Osler; it had no literary merit.

Langdell, and Ames after him, were the opposite of Osler and lived narrow lives. They might have been pioneering doctrinal teachers, but they knew little about the practice of law or about any life outside the academy. Langdell would not have been considered a worthwhile subject for art as in Sergeant's painting or have been the topic of a contemporary Pulitzer Prize-winning biography. His diagnosis of legal problems was not sought by the public. Outside of legal education, few people had heard of him and even fewer cared what he thought. This was not foreordained by any difference between law and medicine. Both professions were and still are large in the public mind. Langdell chose to ignore the world, and it had no choice but to ignore him. ${ }^{147}$

Today, a great many practicing physicians and surgeons know of Osler and the professional values he stood for. On hearing his name, they can state, instantly and with much conviction, that what is wrong with medicine today is the many ways in which managed care prevents them

142 LaPiana, supra note 65, at 13.

143 Bliss, supra note 1 , at ix.

144 Id.

$145 \mathrm{Id}$. at 191.

146 Henry Cushing, The Life of Sir William Osler (1926).
147 Langdell "more than any other man [confined] legal education in a straight mold which was for years to dissociate it from the living context of the world around it." Albert J. Harno, Legal Education in the United States: A Report Prepared for the Survey of the Legal Profession 59 (1953) (emphasis added). 
from practicing medicine as Osler thought it should be practiced. Even a medical student, in a letter to the New York Times, can write, "[A]s the exemplary physician William Osler famously said, 'Listen to your patient, he is telling you the diagnosis."'148

Most law school teachers know, at least vaguely, that Langdell created the classroom version of socratic teaching. But in the legal profession for which he invented the signature pedagogical method, Langdell is virtually unknown. Except for Harvard graduates, who might know why Langdell Hall has that name, practicing lawyers have rarely heard of him, and they have no idea how and why he influenced their education.

The names of both Langdell and Osler have become adjectives, although with very different connotations. In medical education, the term Oslerian is synonymous with the finest professionalism, pedagogy, and intellectual inquiry. To say that a physician or surgeon has Oslerian qualities is considered, in both academic medicine and in the medical profession, to be the highest form of praise. Everyone is assumed to aspire to Oslerian ideals. When modern economic forces diminish the Oslerian tradition, that is regretted by everyone who mentions it. ${ }^{149}$

Langdellian, however, is not an unambiguously favorable term. It's generally used either as a prelude to criticism or as a reference to pedagogical thinking that has both positive and negative characteristics, the negative much more often discussed today than the positive. Almost no one argues now that law schools would be improved if we were to return to the Langdellian classroom in its purest form. Legal education is ambivalent about Langdell-except for his bargain, which both law faculties and university administrators adamantly insist should be strictly observed regardless of its effect on students and the profession they enter. 
